A. n3ailie di is

reapeffie compth sor.

Ste Aw the

OBSERVATIONS, $s c .8 c . s c$

PRICE ONE SHILING AND SIXPEACE 


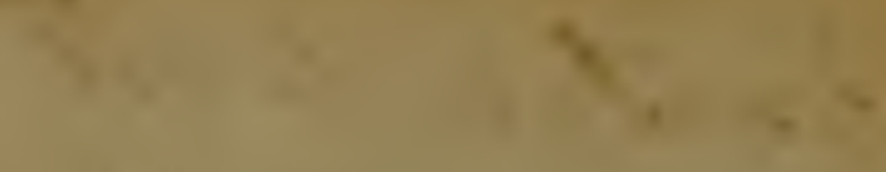

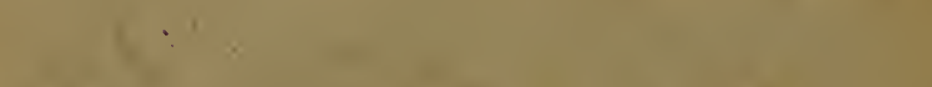

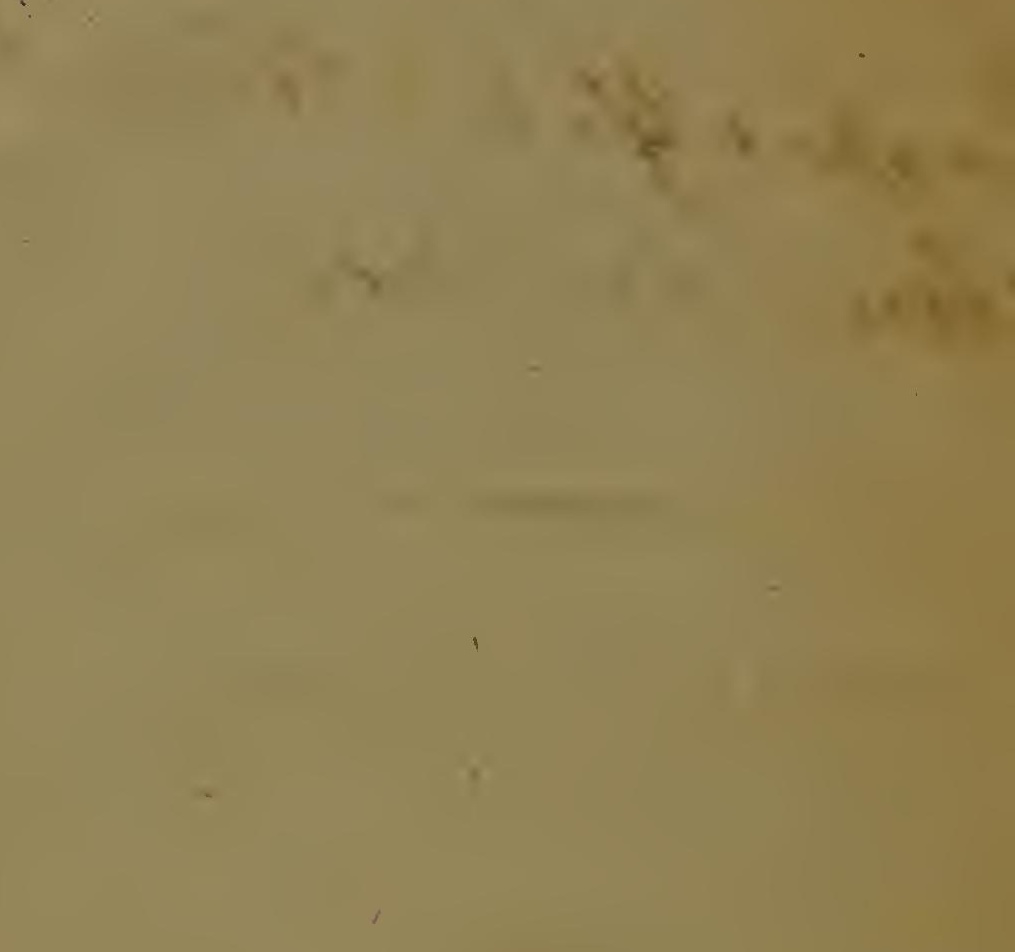

$\infty$

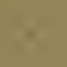

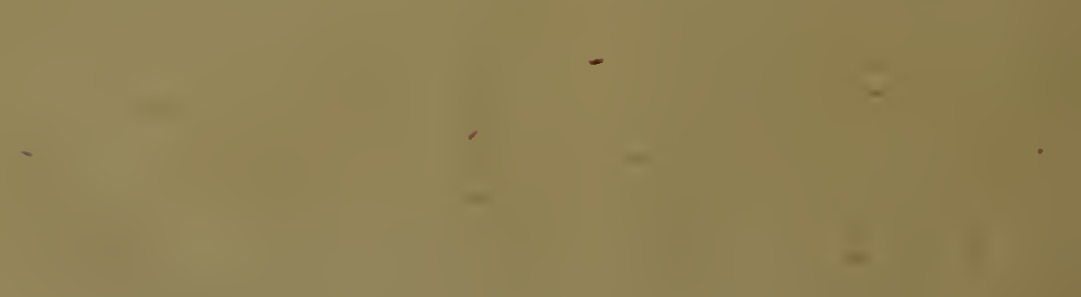




\title{
O BSERVATIONS
}

\author{
ON THE
}

FORMATION AND USES

OF THE

NATURAL FROG OF THE HORSE;

WITH A DESCRIPTION OF

A PATENT ARTIFICIAL FROG,

TO PREVENT AND CURE

CONTRACTED HOOFS, THRUSHES, CANKERS, AND SAND

CRACKS.

BY EDWARD COLEMAN,

Professor of the Veterinary College, \&c. \& $\&$. \&c.

PRINTED FOR THE AUTHOR,

By J. Crowder, Warwick-Square;

AND SOLD AT THE VETERINARY COLLEGE;

AT THE FORGES IN GROSVENOR MEWS, BOND-STREET;

AND LITTLE MOORFIELDS, FINSBURY-SQUARE :

ALSO, BX J. JOHNSON, IN ST. PAUI'S CHURCH-YARE.

1800 



\section{P R E F A C E.}

-

THE principal object of the prefent publication, is to give a defcription of $\dot{a}$ patent Artificial Frog, and to point out the neceffity of its application in the ftable to the natural frogs of horfes, to prevent and cure contracted hoofs, thrufhes, canker, and fand cracks.

But to demonftrate the utility of an artificial frog, it is neceffary to defcribe the ftructure and functions of the natural frog; and in this defcription I fhall be obliged to borrow fome obfervations from my own work on Shoeing, \&c. Unlefs the itructure and functions of the frog of the horfe be well underftood, it is fcarcely poffible to know the great importance of preffure to the health of that organ. 


\section{[ ii ]}

If it be a fact, that the frog is very generally raifed above the furface of the ground, and that the abfence of preffure to the frog in the ftable is the caufe of contracted hoofs, thrufhes, canker, and fand cracks, and that the artificial frog is capable of giving any degree of preffure to the natural frogs of all horfes, even when fhod with the moft common fhoes, fo as to prevent and frequently cure thofe difeafes; then I truft the patent frog will be found an important improvement.

Had it been thought as neceffary for the health of the whole foot that the frog fhould have preffure, as it has been hitherto confidered expedient to raife the frog from the ground, then no doubt a very little obfervation might have fuggent ed the advantages to be derived from an artificial frog.

But the inventive faculties of thofe who attended to this fubject, were employed in a contrary direction and produced a contrary eifeet, They fought not how to give preffure 


\section{[ iii $]$}

preffure to the frog of the horfe; but how to raife it from the ground.

The artificial frogs are fold for three millings each at the Veterinary College: alfo, at the Forges in Grofvenor Mews, Bond-Atreet, and Little Moorfields, Finsbury-fquare, where they are fitted to the feet of horfes without any additional expence.

They are alfo fold by the Veterinary Surgeons who have quitted the College, and may be had in mort of the principal towns in the Kingdom. 


\section{II) \\ (1)}

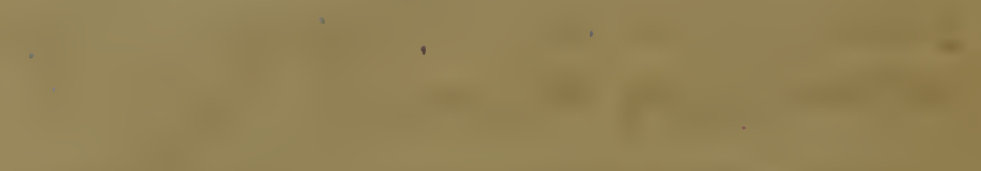

-

$x^{2}+1$

$x^{2}=x^{2}$

and

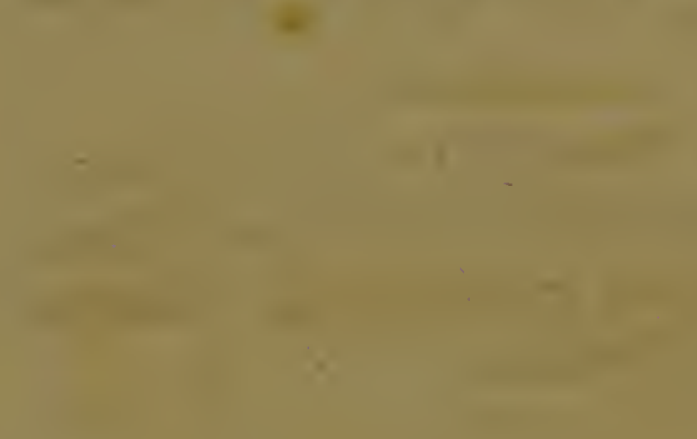

$\infty$

$$
-1=
$$

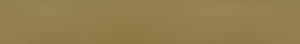

$n^{i}$

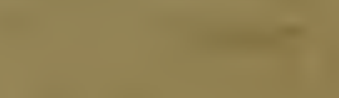

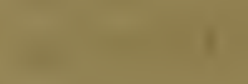
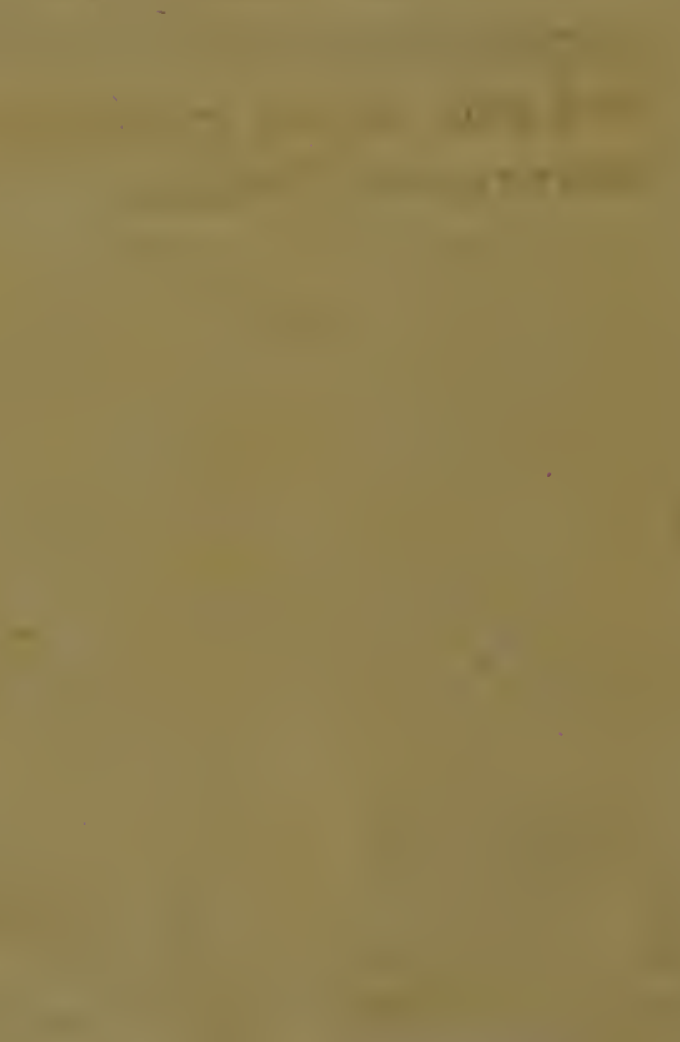


\section{OBSERVATIONS, $\varepsilon_{c:}$}

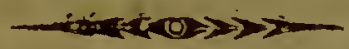

THE natural Frog of the Horfe is placed in the centre of the fole, externally convex, and of a wedge-like form, pointed towards the toe, but expanded as it advances to the heels. In the centre of the broad part there is a fiffure, or feparation. The frog is connected internally, with another frog, of a fimilar figure, but different in ftructure. The external frog is compofed of foft elaftic horn, and totally infenfible. The internal frog has fenfation and is much more elaftic than the horny frog; and at the extremity of the heels is connected with two elaftic fubftances called cartilages. The toe of the fenfible frog is united to the coffin bone; but more than nine tenths of both frogs are behind the coffin 


\section{$[2]$}

bone. The toe of the fenfible and horny frogs, from their connexion with the coffin bone, are fixed points, and have no motion; but the heels of the frogs being placed pofterior to the coffin bone, and in contact with move. able, elaftic, (and not fixed or refifting) fubftances, a very confiderable lever is formed, and whenever the horny frog comes in contact with the ground, it firft afcends, and then defcends. The preffure of the ground alfo expands the horny frog, and the fenfible frog expands the cartilages, and at the heels and quarters immediately below the hair, totally governs the direction of the future growth of the cruft.

This afcent of the frog, not only by its wedge-like form preferves the heels and quarters from contraction, but affords to the horfe an elaftic fpring, and prevents the animal from flipping whenever it embraces the ground. Without any anatomical enquiry into its internal ftructure and union with other parts, the thape and convexity of the horny frog clearly demonftrates that it was formed to come into contact with the ground.

We cannot fuppofe that the all-wife Creator would have made an organ, much expofed to injurys 


$$
\text { [ } 3 \text { ] }
$$

injury, without making its ftrueture adequate to its function. Animals deftined for a cold climate are provided with a much warmer covering than animals in' a higher temperature: the eye is admirably conftructed for receiving light; the ear for the vibrations of found; and every organ, in every animal, is beautifully formed to anfwer its peculiar ufe. Shall we then doubt that the frog is made with the fame degree of wifdom as other organs? Shall we not conclude that it was intended to receive preffure, fince its convexity muft make it liable to touch the ground at every ftep? The more I inveftigate this fubjest, the more I am convinced that the ure of the frog is to prevent the horfe from llipping, to preferve the cartilages and hoof expanded, and, by its motion, to act as an elaftic fpring to the animal.

Mr. Saintbel, and many others were of opinion, that the ufe of the frog, is, to ferve as a curhion, or guard to the tendon of the flexor mufcle of the foot. Where this opinion prevails, it is very natural to conclude, that art fhould endeavour to raie the frog from the ground, by a thick heel'd Thoe, in ordes to guard the tendon from bruifes. But, if it be

a truth 


\section{$\left[\begin{array}{lll} & 4 & ]\end{array}\right]$}

a truth that this projecting body was intended to receive the preffure of the ground, then it will follow, as a law of nature, that unlefs the frog performs its functions, it muft become difeafed.

The human legs are formed to move and fupport the weight of the body; but if they are kept in a horizontal pofture, in a fate of reft, the whole machine will foon bècome enfeebled and direafed. The horfe is an animal intended for active life, but if he is fuffered to remain without motion, not only his legs but his whole fyftem becomes affected. Indeed, common obfervation clearly proves, that no animal, or any part of any animal, where the natural functions are perverted, can be preferved in health. If the real œconomy of the frog had been cqually well underfood, it would have been thought as neceffary, for the health of that organ, that it fhould receive preffure, as we know it to be important for the health of the horfe to have motion.

It is therefore as great an aft of violence to the frog, to raife it from the ground, and muft as neceffarily produce difeafe, as to deprive mufcles of action. That the frog was rot made to defend the tendon, can be demonfrated. There is no medical man, acquainted 


\section{$\left[\begin{array}{ll}5 & 0\end{array}\right]$}

quainted with the ftructure and œconomy of tendons, but muft be convinced, that the frogs of horfes are formed for other functions. It has been proved by experiment, that the fubftance of tendons in liealth has no fenfation; and, confequently, that on infenfible body (viz. the frog) cannot have been made for the purpore of protecting an organ void of feeling. Again, the frog, being made of a wedge-like form, a great part of the tendon is not covered by the frog, and more than one half of it projects behind the tendon. If the frog had been made to act as a curhion, to fave the tendon, then its hape and magnitude would have been exaßty equal to the tendons.

The practice of fhoeing very much depends on the functions of the frog being underftood. If the opinions here advanced refpecting its ufes, be well founded, then it muft follow, that paring the frog, and raifing it from the ground annihilates its functions, and ultimately, if not immediately, produces difeafe; and that expofing the frog to preffure, is the only proper method to keep it in health. "Moreover, it has from experience been afcertained, that unlefs the frog fuftain an uniform preffure, when at reft, the heels as well as the frog con- 


\section{$\left[\begin{array}{lll}6 & 6 & ]\end{array}\right.$}

tract, but if that organ be in clofe contact with the ground, then it fpreads and is free from thruhes and canker, and operates as a wedge to keep open the heels of the hoof.

The fame degree of perpendicular preffure* applied to the infenfible frog, that produces only pleafant enfation to the fenfible frog when in health, creates exquifite pain when difeafed. It is therefore of great importance to preferve the frog found, for when contracted or cut, or inHlamed, it becomes highly fufceptible of every impreffion; we might with as much wifdom contract the thoe of the human fubjest, or remove the fkin of the foot, when obliged to walk on fones without fhoes.

Granite and other hard fubftances, give no pain to a frog expofed to conftant preffure in the fable; but when above the pavement, it generally becomes contracted, and the fenfible frog inflamed, and then one froke from a projecting fone, will produce pain, perhaps lamenefs, while perpetual perpendicular preffure is attended with falutary effects.

Thofe who conceive, that the frog was not made to come in contas with the ground, and

*. By perpendicular preffure, I mean that preffure the frog meets with from the ground, and not the lateral preffure of a contracted hoor. 


\section{[: 7 ]}

and with that view cut the frog, to diminifl its convexity, and employ high heeled hoes for its protetion, would do well to confider, whether their practice is in truth conformable to their own principles. If it be true, that no thoe, however high at the heel, applied to any hoof, can prevent the frog from occafionat preflure, then it muft follow, that the practice and principles do not agree; and it is obvious, that no frog is totally exempt from preffure, even if the thoe be turned up two inches at the heels.

Where the roads are covered with a convex pavement, or with loofe ftones, the frog is liable to be ftruck by every ftone that exceeds the thicknefs of the thoe; and in other fituations, where there are no fones, the cavity of the thoe is filled with earth; fo that the frog, when the horfe moves, is expofed to unequal furfaces, and confequently receives frequent preffure. It therefore becomes a queftion, whether repeated blows on a part that has been raifed, on the average, five-fixths of the twenty-four hours above the ground of the ftable, and from the abfence of preffure made very. fufceptible of impreffion, will not produce more pain, and more difeafe, than conftant and uniform preffure. 


$$
\text { [ 8. ] }
$$

When a flarp ftone comes in contast with a foft and thin frog, horfes are liable to fall. It may therefore be imagined, that if a horfe feels pain from the preffure of one blow, great mifchief muft enfue, when the fame caufe is many times repeated; and that the effect or. difeafe muft increafe in proportion to the caufe. But it has not been confidered, that in con-. fequence of always ftanding on the frogs on hard furfaces, in the ftable, thefe organs re. tain their natural infenfibility and elafticity, and refift even the hardeft bodies without the leaft irritation: Do we not fee that the fkin of the palms of hands of fmiths and watermen, become thickened and callous, and feel no in. convenience from fubftances that would $a b$ folutely blifter a hand, in the habit of wearing gloyes? And, is it not a fait, that the fole of the human foot is equally void of feeling, with thofe perfons who are accuftomed to. walk without thoes? A man obliged to travel on harp ftones would not think it prudent to lay up his legs, and give the foles. of his feet no preffure within doors. If the. hoof of the horre was always expofed to na: tural air and moitture, and the frog to irregular furfaces, the form of the thoe would be of lefs confequence. But as in the ftable the frog is very generally raifed above the ground, 


\section{$\left[\begin{array}{lll}2 & 9\end{array}\right]$}

ground, the artificial heat tends powerful ly to contract the heels of the hoof. When the hoof contracts, the frog muft alfo become contra\&ted, and inflammation and a fuppuration follows, called a Thrufh. Na contraction, however, takes place, where the frog is made to receive conftant preffure, as the ftanding perpetually on that wedge encreafes its growth, preffes upward the fenfible frog, and expands the cartilages of the hoof. And as the firft Shoot of the cruft at the coronet is very thin, the direction of its fibres will be altogether regulated by the width of the cartilages immediately below the hair at the quarter's and heels, and the cartilages will be always more or lefs expanded, and the hoof more or lefs circular, as the frog has more or lefs preffure.

On that principle I long fince recommended a fhoe with thin heels, as the befe formed floe to bring the frog on the fame level; and with great truth $I$ can affert, that, although in fome inftances, from a fudden mifapplication of the thin heel'd thoe to improper feet, I have feen the tendons affe?ted, yet from all the experience $I$ have fince had, and from all that $I$ have feen or heard of the practice of others, I know of no inftance where the frog, from conftant preffure, aid not expand 


\section{$[10]$}

pand and receive great benefit. Neither is it true, as has been afferted, that the frogs of horfes, from the preffure of the ground, are made inelnfic, and incapable of motion. It is as totally contrary to the invariable laws of nature, that an organ fhould, in confequence of performing its natural functions become difeafed; as it is an invariable principle, that an organ deprived of its functions cannot continue in health. I have particularly examined the ftructure of many hundred frogs, in hoofs hod with various hoes, and I have uniformly found, that in proportion as the foot is contracted, it becomes hot and inflamed; and if the frog be not deftroyed by thrufhes or canker, it is brittle and inelafic. But where the frog has been conftantly on a level with the heels, whatever may have been the form of the fhoe, or without thoes, the hoof remains circular, and the natural form and elaftic ftructure of the frog is preferved.

The inelaftic quality therefore of the frog, fo far from taking place in confequence of the preffure of the ground, proceeds wholly from contraction, and contraction from the want of perpendicular preffure.

Where the frog conftantly meets the ground in the ftable, the heels are open, and the 


\section{$\left[\begin{array}{lll}11 & ]\end{array}\right]$}

frog elaftic, expanded and healthy; but where the cavity of the horny frog is contracted; the fenfible frog is violently fqueezed, and becomes hot and inflamed, and from this heat the horn is dry and inelaftic.

Thofe who from falfe kindnefs raife the frog from the ground, to prevent preffure, will probably be furprifed at the. affertion, that the fenfible frog fuffers moft pain and moft preffure when moft raifed from the ground.

It is, neverthelefs, literally true ; for in proportion as the frog is free from perpendicular preffure, the heels of the hoof contract; and, as the hoof contraets, the frog alfo becomes contrakted; and, in proportion to the degree of contraction, the fides of the fenfible frog, without any refpite, muft receive lateral preffure from the fides of the horny frog. Perpendicular preffure is natural both to the horny and fenfible frogs, and the afcent of thofe organs prevents concuffion and preferves them in health. But nature has made no provifion for permanent unnatural preffure, produced by a contraction of the cavity of the horny frog, and it has certainly not been confidered that the frog fuffers the greateft violence ${ }^{\circ}$ and more preffure, when raifed from, than when in contact with, the ground.

Where 


\section{$\left[\begin{array}{lll}1 & 12\end{array}\right]$}

Where the frog is in a morbid ftate, and unnaturally deprived of perpendicular preffure, it-is feldom fafe to lower the heels at once, fo as to make the frog on a level with the thoe; and, in many cafes, it is not polible with any fhoes, or even without fhoes, to give the frog preffure on fmooth furfaces; much lefs is it practicable for the frog to reft on the ground when fhod with common thickheeled fhoes. In the ftable, therefore, while at reft, the frog is generally raifed above the thoe, and as preffure is effential to its health, particularly when the hoof is expofed to heat, it appeared to me of great importance, in all cafes where the heels of the fhoe and the frog cannot with fafety be made on the fame level, to apply an artificial frog, to fit and give any degree of preffure, in the ftable, to the natural frog, with any thoes. With that vicw, I firf cmplayed plaifter of Paris, but from its tender texture, that application was found to fail, and Mr. Rickword, a very intelligent pupil of the college, propored to employ leather, and to. conneet it with the thoe by frings. This plan alfo did not fucceed, but I think it a duty due to Mr. Richord, to mention, that in the con-: flruetion of the artificial frog, I have received çonfiderable affiftance from his attention and ingenuity. 


\section{$\left[\begin{array}{lll} & 13 & \end{array}\right]$}

ingenuity. While the horfe is in motion, and the hoof expofed to unequal furfaces, the artificial frog thould be removed, as the natural frog, out of the ftable, will receive frequent preffure with any thoes; but that period is of hort duration, when compared to the length of time the horfe remains at reft, and the frog raifed from the ground.

Artificial preffure is moft particularly wanted when the heat of the ftable operates powerfully to contract the hoof. In all cafes, therefore, zohere the pavement of the fable does not touck. the natural frog, an artificial frog is necefary to refift contraction of the hoof, thrufhes, and canker. Sand-cracks, alfo, very generally arife from a contracted hoof, and may be prevented by the artificial frog.

If the frog does not abfolutely reft on the pavement, whatever hoes are employed, the hoof in the ttable will be as much difpofed to contract, as if the frog was raifed any greater diftance. I winh this fact to be well confi. dered; for it has been fuppofed that fhoes with a flat feat, without preffure to the frog, will prevent contraction. But I am fully convinced that neither thick nor thin heeled thoes, where the frog is raifed above prefliere, and expofed to the heat of the Rable, can prevent 


\section{[ 14$]$}

contraction, or its effects; and where the frog receives that preffure, the heels cannot contract even with the moft common fhoes. For very obvious mechanical reafons, a wedge in the centre of the heels, aided by the preffure from below, mut be beft calculated to preferve them expanded, or when the heels are contracted, to force them open. The heat of the ftable in all cafes tends to contrastion of the hoof: but with common fhoes there is no preffure on the wedge, or other caufe to counteract that tendency. The artificial frog, which is intended to cover and give any degree of preffure to the natural frog only, is made of iron. In order to fit the natural frog, it is requifite to afcertain its width, the length of the foot, and the diftance between the lower furface of the thoe and the frog. But if the artificial frog be too long, the toe, which is flat and thin, may be thortened; and if the heels of the thoe are higher than the artificial frog, nothing more is requifite than to introduce a quantity of tow between the natural and artificial frog, fo as to raife it equal or above the level of the fhoe. I have afcertained by experience, that no inconvenience takes place by raifing the artificial frog even one quarter of an inch above the thoe; but in ordinary cafes, it mould not 


\section{$\left[\begin{array}{lll}1 & 15\end{array}\right]$}

projeet more than one fixth of an inch above the furface of the thoe. It may, however, be imagined, that fo much perpendicular preffure to the frog would retard rather than in creafe its growth. But the very reverfe is the faet : for as the frog; when long elevated above the ground, is very generally contracted, this unnatural lateral preffure excites inflammation of the fenfible frog, and deprives in a great degree the blood veffels of the power of fecreting horm. When the horny frog is expofed to perpendicular preffure, it gives health, and not difeafe, to the fenfible frog. The blood veffels fecrete their due proportion of elaftic horn, and then the cavity of the frog is preferved, expanded, and fully equal to contain the fenfible frog, without the fmalleft degree of lateral preffure.

It therefore follows, that perpendicular preffure encreafes the bulk of the frog; while its abfence from the ground produces contraction, and leffens its growth.

Neither is this fact in any refpeet peculiar to the frog of the horfe. The cuticle, or outer fkin of the human feet and hands, always grows in proportion to the quantity of preffure. Thefe parts grow from within outwards, and the blood vefiels will be ffimulated to fecrete 


\section{$\left[\begin{array}{ll}16 & ]\end{array}\right.$}

more or lefs horn, or more or lefs khin, as they receive preffure.

The veffels of the fkin of the hand, or of the fenfible frog of the horfe; that have but little preffure, will produce only a very thin and delicate covering. Give more preffure, and nature will furnifh an adequate quantity of infenfible matter to protect thofe parts from injury. The toe of the artificial frog is intended to be inferted under the toe of the fhoe. This effectually fixes the frog forwards, and to prevent backward or lateral motion, an irregular groove is made in the iron frog, to receive a correfponding piece of fteel, placed under the hecls of the thee. In general it is neceffary to fix the frog more firmly, and, for that purpofe, a hole is neceffary, made in the heel of the artificial frog, to receive a ftrap, and. to buckle at the outfide quarter below the coronet. And that the artificial frog may give preffure in all cafes with floes thickened, or turned up for hunting or froft, a variety of frogs are made, to be adapted to particular feet and particular thoes. In cafes of thrufhes and can. ker of the frog, where no remedies without preffure are likely to be forviceable, an aftringent thrufh powder may be applied between the natural and artificial frog. And in contracted hoofs; (or what has improperly becin termed cheft 


\section{$\therefore\left[\begin{array}{lll}17 & 17\end{array}\right]$}

foundered,) where it may not be advifable to lower the heels equal with the horny frog, the artificial frog is effentially neceffary.-But indeed in'every horfe where the fhoe and frog on a fmooth furface are not on the fame level, whatever fhoes may be ufed, the iron frog in the ftable Thould be applied, and in order to fix it with facility, the fpring fhould firft be Placed under the fhoe and brought backward to the heels of the hoof.

The toe of the iron frog flould then be inferted under the centre of the fpring, and pufhed as far as the toe of the fhoe, while the other hand confines the fpring until the centre of the fpring meets the centre of the groove. The frap may then be buckled. And to diflodge the fpring and iron frog, after the ftrap is unbuckled, nothing more is requifite than a fmall horfe picker, introduced into a hole at the bottom of the groove of the iron frog; and the fpring being raifed above the groove and carried gently forward, the frog may be withdrawn from under the fhoe without the fmalleft difficulty.

It may be proper to add, that there is no caufe of lamenefs from common fhoeing fo frequent as contraction of the hoof and frog, and as thofe difeafes are productive of violent pain to the animal, it.muft afford great fatisfaction 


\section{$\left[\begin{array}{ll}18 & 18\end{array}\right]$}

to the mind of every humane man to be informed, that by the affiftance of a fimple machine, that perpetual torment under which fooner or later mott of the horfes of this country labor, may be effectually prevented. A thoe too fmall for the human foot gives confiderable pain, even when worn for a thort period, but the hoof of the horfe when the frog has no perpendicular preffure, every day becomes more and more contracted, and gives more and more lateral preflure to the fenfible parts of the foot, and with this permanent pain the horfe is frequently obliged to fupport additional weights. Perpendicular preffure on the frog, preferves not only the frog, but the whole hoof of the fame form as it comesfrom the hands of the Creator. Neverthelefs there are many perfons who doubt the good effects of thin hecl'd fhoes, or of bringing the frog in any cafe on the fame level with the ihoes. But fince my publication on the foot of the horfe, longer experience has not altered, but confrmed my opinion on that fubject; and under the circumfances and precautions already pointed out in that work, I do not believe it poffible for my judgment to waver.-I beg therefore to be clearly underilood, that in all cafes where the frog and the 


\section{$\left[\begin{array}{ll}19 & ]\end{array}\right.$}

heels of the fhoe are placed on the fame level, the patent frog is umecefory. But where the frog is fmall, or the pafiern joint long, or the action of the animal high, or the heels low, fo as to render the application of thin heel'd fhoes improper, or when the frog from any caufe is raifed above the ground in the ftable, an artificial frog is ufeful in all fuchcafes, and neceffary to refift contraction of the hoof. But if thin heel'd thoes were productive of mifchief, or if my opinion had mifled me to recommend in all cafes thick thoes to protect the frog from injury, ftill my prefent opinion, as to the neceffity of giving preffure to the frog in the ftable, when at reft and expofed to heat, would iilil be the fame. Whatever may be the thicknefs of the fhoe, there are ftones ftill thicker, and to enable the frog when in motion to bear fuch preffure without pain or mifchief, and to refift the influence of heat, and to keep the hoof and frog expanded, perpendicular preffure to the frog in the ftable muft be always beneficial. To raife the frog from preffure when at $r e \ell$, and yet to expore it to fhàrp and hard bodics when combined with force and conftant aftion, muft be obviounly deftrultive to the aconomy of the whole foot, and to the fenfible parts in particular. 


\section{[ 20 ]}

It therefore follows, that whether it be proper or improper for the frog to touch the ground while in motion, no one with any propriety can doubt the neceffity of giving preffure to the frog when at perfeet reft and expofed to artificial heat. 


\section{EXPLANATION}

oF

THE PLATES.

FIGURE THE FIRST.

A view of the natural hoof of the Horfe, of a circular thape.

a $a$ a The external furface of the fole of a concave form.

$b b b$ The inferior edge of the cruft.

$c c$ The junction of the bars with the cruft.

$d d$ The points of the bars.

e $e$ The fole between the heels of the cruit and bars, the feat of corns.

ff Two cavities between the fides of the bars and the fides of the cruft.

$g$ The toe of the frog.

$h h$ The heels of the frog.

$i i$ The cleft between the heels of the frog, the feat of thruntes. 


\section{$\left[\begin{array}{ll}2 & 2\end{array}\right]$}

FIGURE THE SECOND.

A view of the hoof with contrased heels, produced by raifing the frog above the preffure of the pavement in the frable.

$a$ a $a$ The fole.

$b b$ The original feat of the bars, but improperly removed by the farrier.

$c c$ The original feat of the cavities between the bars and cruft, but now from contraction a folid horn.

d d The heels of the frog very much compreffed, by the contraction of the hoof.

ec The width of the hoof at the heel, not being more than one half of the length from $f$ to $g$.

$f \quad$ The extremity of the heels of the frog.

$g$ The toe of the cruft.

FIGURE THE THIRD.

A view of the patent frog, made of caft and wrought iron.

is a The lower furface oppofite the ground, formed of caft iron.

6 An irregular cavity for the reception of ali elaftic fpring. Fig. iv.*

c The

* In the forc part of this cavity there is an opening for the point of a picker to renove the fipring, but which has been omitted in the plate of outlines. 


\section{$\left[\begin{array}{ll}2 & 23\end{array}\right]$}

c The toe of the patent frog, formed of wrought iron, to be occe fionally fhortened and adapted to the length of the foot, and piaced under the toe of the fhue to confine the artificial frog from moving forwards. d d A hole in the heeis of the iron frog, for the paffage of a frrap to buckle at the outfide quarter or coronet.

\section{FIGURE THE FOURTH.}

$A$ view of a flat fteel fpring to fix the artificial frog.

a An irregular projection, to be received into a correfponding concavity in the patent frog.

$b b$ The ends of the fpring, to be placed under the heel's of the fhoe oppofite $c e$, in Fig. 1.

\section{FINIS.}

Printed by J. Crowder, Warwick Square. 


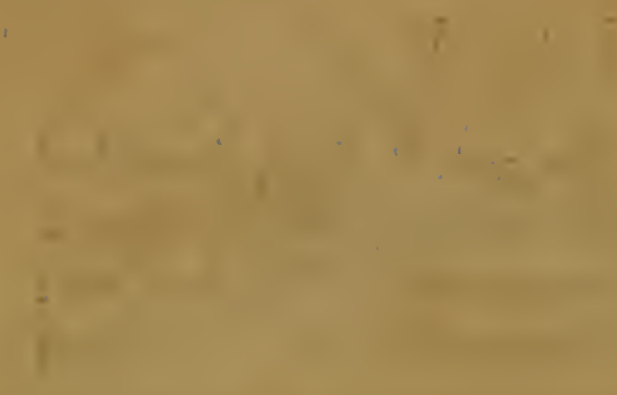

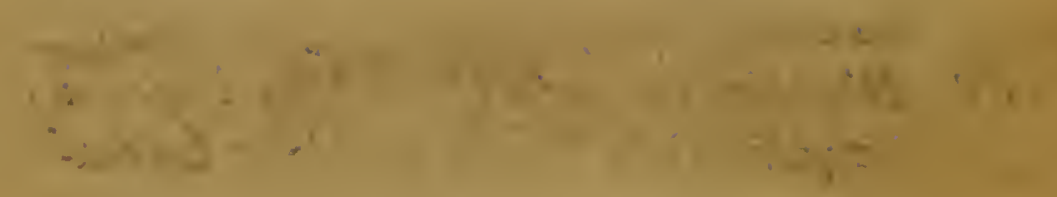

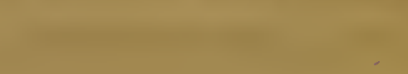

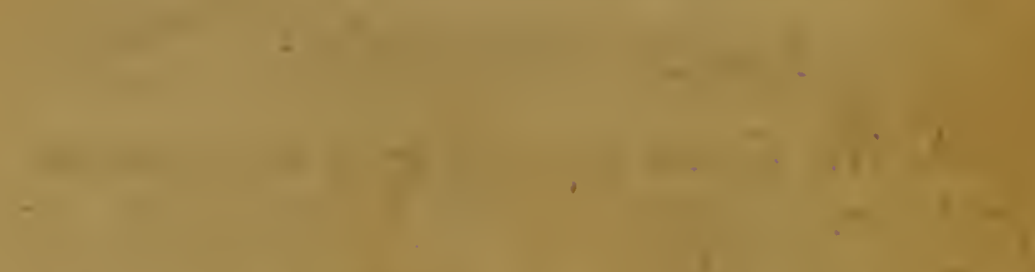

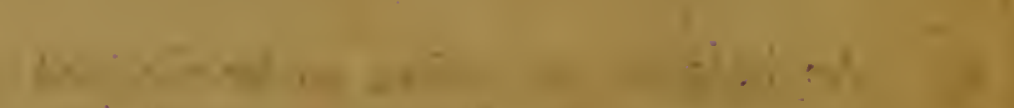

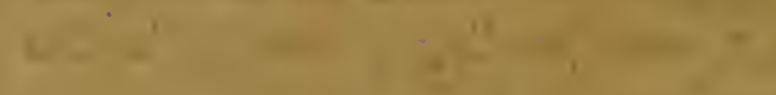

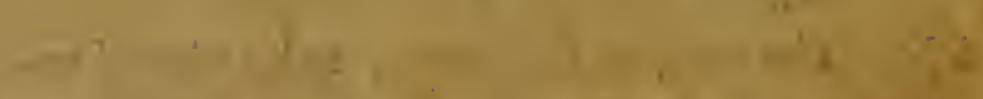

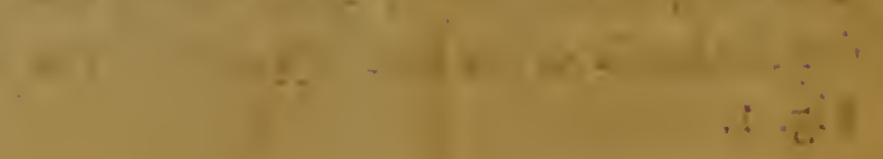

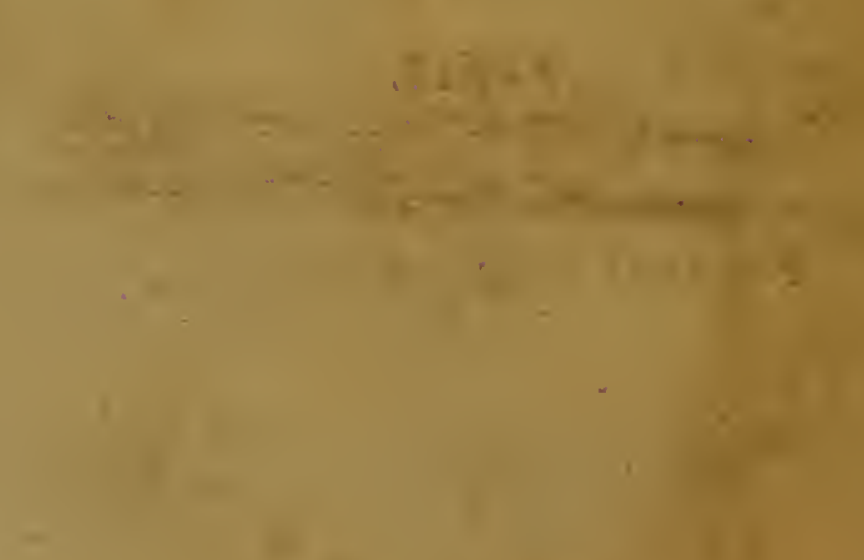




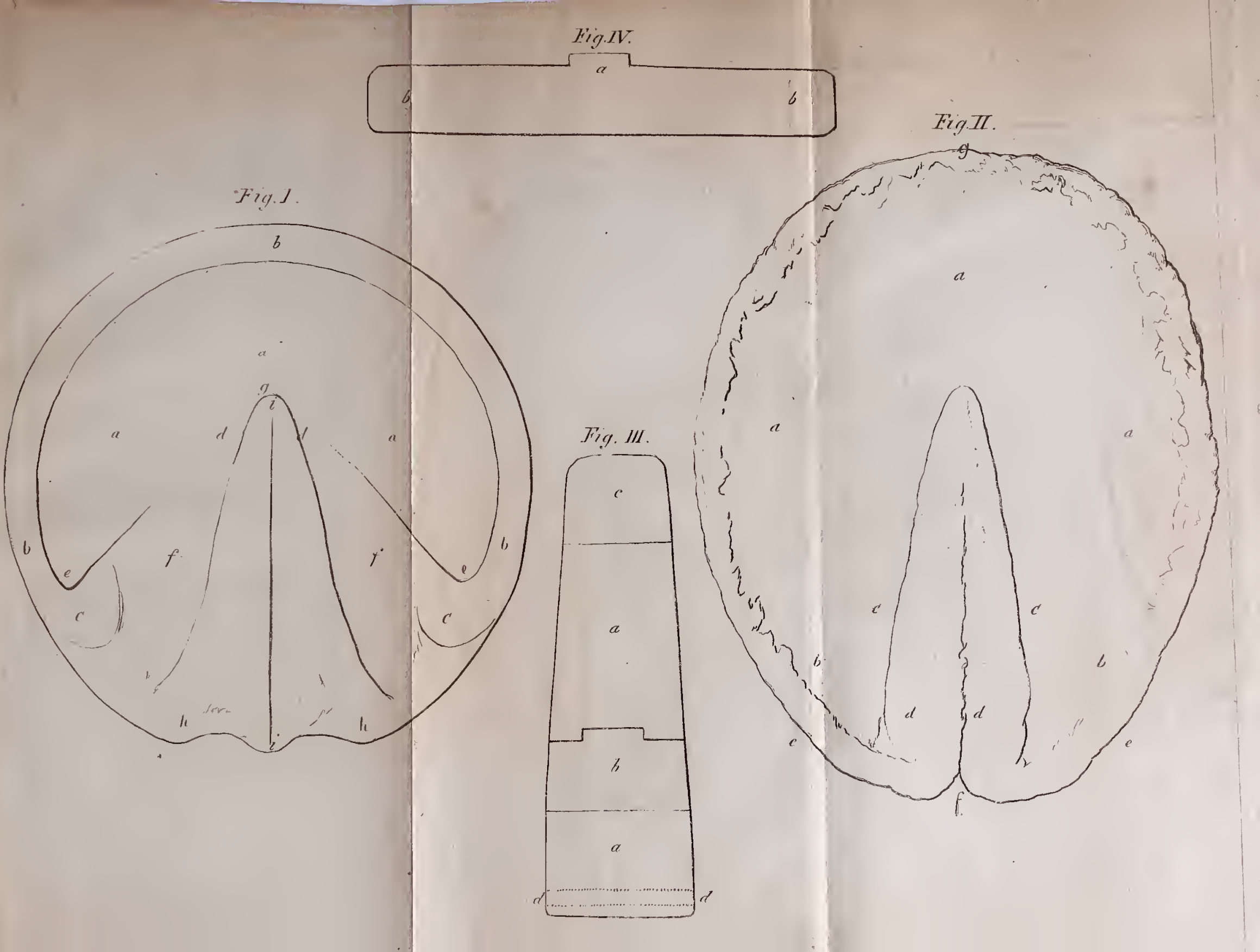



c) (Prefert istort.

el Contracted Frot.

